\title{
Peningkatan Keterampilan Menulis Teks Biografi Melalui Penerapan Metode Quantum (Tandur) pada Siswa Kelas X SMA Yayasan Purwa Bhakti Ciawi Bogor
}

\author{
Oleh: \\ Eri Sarimanah', Muh. Rizky Ali Nashir ${ }^{2}$ \\ 1, Pendidikan Bahasa dan Sastra Indonesia, FKIP UNPAK, Bogor \\ 2, Pendidikan Bahasa dan Sastra Indonesia, FKIP UNPAK, Bogor
}

\begin{abstract}
The aim of the research is to know the improvement of writing biography text through method of quantum (TANDUR) and to improve the effectiveness of the students study in writing biography text for grade 10 students of Yayasan Purwa Bhakti Ciawi Bogor. The hypothesis of this research is the there is improvement and the effect of student's ability to write the biography text through method of quantum (TANDUR). The hypothesis can be accepted and be showed with the score average from the students and also can be showed with the result of observation that be done by two collaborators to know the effectiveness of students study. The writing skill in writing biography text can be improved after the researcher used the quantum (TANDUR) as the method in learning process. That was showed with increasing of the score average in each and every cycle. The score average of pre-test is 59,8 or $60 \%$ in percentage. In cycle I obtained the increasing of the score average become 72 or $72 \%$ and in cycle II obtained the significant score 81,6 or $82 \%$. The success of writing ability in writing biography text after be applied of quantum (TANDUR) method in classroom action research showed the improvement with the score average $82 \%$. In addition, the difference significantly between the results of test in cycle I obtained $72 \%$ and $82 \%$ in cycle II. It showed successfulness in applying the method of quantum (TANDUR) through improve the writing ability in writing biography text.
\end{abstract}

Key words: Writing Ability, Writing Biography Text, and Method of Quantum (TANDUR).

\begin{abstract}
ABSTRAK
Tujuan Untuk mengetaui peningkatan keterampilan menulis teks biografi melalui metode quantum (TANDUR) dan kendala yang dialami oleh siswa dalam menulis teks biografi. Metode yang digunakan dalam penelitian ini adalah metode penelitian tindakan kelas teknik pengumpulan data tes, angket, dan observasi. Populasi dalam penelitian ini adalah SMA Yayasan Purwa Bhakti Ciawi Bogor. Sampel dalam penelitian ini adalah kelas X-A. Teknik pengambilan sampel cluaster random sampling. Hipotesis penelitian ini adalah terdapat peningkatan keterampilan menulis teks biografi melalui metode quantum (TANDUR) terbukti dari hasil pengamatan (observasi) terhadap efektivitas belajar peserta didik yang dilakukan oleh dua kolaborator. Keterampilan menulis Teks Biografi meningkat setelah dilakukan pembelajaran melalui metode quantum (TANDUR). Hal itu ditunjukkan dengan peningkatan nilai rata-rata pada setiap siklusnya. Nilai rata-rata prates menulis Teks Biografi di kelas X yaitu 59,8 atau 60\% saat postes siklus I nilai rata-rata keterampilan menulis Teks Biografi meningkat menjadi 72 atau $72 \%$. Sedangkan saat postes siklus II nilai rata-rata kemampuan menulis Teks Biografi meningkat secara signifikan menjadi 81,6 atau 82\%. Keberhasilan kemampuan menulis Teks Biografi setelah menggunakan Metode quantum (TANDUR) pada penelitian tindakan kelas menunjukkan peningkatan dan mencapai ukuran keberhasilan belajar tuntasnya dengan nilai rata-rata $82 \%$. Dengan demikian keberhasilan penerapan metode quantum (TANDUR) terlihat pada perbedaan yang signifikan antara hasil tes menulis Teks Biografi pada postes mengalami peningkatan sebesar $72 \%$ siklus I dan $82 \%$ pada postes kedua siklus II.
\end{abstract}

Kata kunci: Keterampilan Menulis, Teks Biografi, Metode Quantum (TANDUR). 


\section{PENDAHULUAN}

Kemampuan menulis sangat bermanfaat bagi siswa selama mereka belajar di sekolah maupun di luar sekolah, agar siswa menguasai tata cara penulisan yang baik dan benar. Selain itu siswa dapat menangkap isi-isi pokok yang ada dalam teks.

Menulis adalah sebuah kegiat-an menuangkan pikiran, gagasan, dan perasaan seseorang yang diungkapkan dalam bahasa tulis. Dalam pengertian yang lain, menulis adalah kegiatan untuk menyatakan pikiran dan perasaan dalam bentuk tulisan yang diharapkan dapat dipahami oleh pembaca dan berfungsi sebagai alat komunikasi secara tidak langsung. Dengan demikian, dapat kita tegaskan bahwa pengertian menulis adalah ke-giatan seseorang untuk menyampaikan gagasan kepada pembaca dalam bahasa tulis agar bisa dipahami oleh pembaca.

Menulis berarti menuangkan isi hati si penulis ke dalam bentuk tulisan, sehingga maksud hati penulis bisa diketahui banyak orang-orang melalui tulisan yang dituliskan. Kemampuan seseorang dalam menuangkan isi hatinya ke dalam sebuah tulisan sangatlah berbeda, dipengaruhi oleh latar belakang penulis. Dengan demikian, mutu atau kualitas tulisan setiap penulis berbeda pula satu sama lain. Namun, satu hal yang penting bahwa terkait dengan aktivitas menulis, seorang penulis harus memperhatikan kemampuan dan kebutuhan pembacanya.

Untuk mengoptimalkan dan meningkatkan kemampuan menulis siswa maka, penulis ingin menggunakan Metode Quantum (TANDUR) dalam pembelajaran. Quantum learning merupakan kiat, petunjuk, strategi dan seluruh proses belajar yang dapat mempertajam pemahaman dan daya ingat, serta membuat belajar sebagai suatu proses yang menyenangkan dan bermanfaat. Quantum learning ini berakar dari upaya Georgi Lozanov, pendidik berkebangsaan Bulgaria. Ia melakukan eksperimen yang disebutnya suggestology. Prinsipnya adalah bahwa sugesti dapat dan pasti mempengaruhi hasil situasi belajar, dan setiap detil apapun memberikan sugesti positif atau negatif.

Tokoh utama di balik Quantum Learning adalah Bobbi DePorter. Dia perintis, pencetus dan pengembang utama Quantum Learning. Sejak tahun 1982 DePorter mematangkan dan mengembangkan gagasan Quantum Learning di SuperCamp. Dengan dibantu oleh temantemannya, terutama Eric Jansen, Greg Simmons, Mike Hernacki, Mark Reardon dan Sarah Singer Nouric, DePorter secara terprogram dan terencana mengujicoba gagasan-gagasan Quantum Learning kepada para remaja di SuperCamp salama tahuan awal 1980-an. DePorter menjelaskan bahwa metode ini dibangun berdasarkan pengalaman dan penelitian terhadap 2.500 siswa dan sinergi pendapat ratusan guru di SupeCamp. Prinsip-prinsip dan metode-metode Quantum Learning ini dibentuk di Super Camp.

Dengan adanya metode ini maka, daya ingat anak akan meningkat sehingga dapat membantu anak untuk mengingat isi pokok yang ada dalam teks. Dengan begitu anak akan mudah dalam menulis teks.

Penulis menggunakan sarana teks Biografi dalam penelitian ini karena, penulis ingin menghubungkan dengan pengetahuan anak tentang tokoh-tokoh pahlawan yang ada di Indonesia. Selain 
siswa mempunyai daya ingat yang kuat tentang kebahasaan, siswa juga mempunyai daya ingat yang kuat tentang pengetahuan tokoh-tokoh pahlawan di Indonesia.

Menulis teks negosiasi agar siswa tidak lagi mendapatkan nilai dibawah rata-rata. Salah satu caranya yaitu menciptakan suasana belajar yang lebih kreatif dan inovatif serta menggunakan model pembelajaran yang mampu membuat siswa nyaman dalam proses pembelajaran menulis teks negosiasi.

Berdasarkan identifikasi masalah di atas, perumusan masalah dalam Penelitian Tindakan Kelas (PTK) ini adalah sebagai berikut :Bagaimana proses pelaksanaan pembelajaran meningkatkan kemampuan menulis teks biografi siswa SMA Yayasan Purwa Bhakti Ciawi Bogor dengan menggunakan Metode Quantum? Adakah peningkatan kemampuan menulis teks biografi siswa SMA Yayasan Purwa Bhakti Ciawi dengan menggunakan Metode Quantum?

\section{Pengertian Menulis}

Keterampilan menulis merupakan bagian dari keterampilan berbahasa lainnya, seperti keterampilan menyimak, membaca, dan mendengarkan. Dari empat keterampilan tersebut, keterampilan menulis merupakan kegiatan yang paling tinggi yang harus dimiliki seseorang karena dalam keterampilan ini mereka dituntut untuk mampu menuangkan ide yang mereka miliki ke dalam tulisan, dan mampu merangkai kata-kata yang mereka tulis dari yang sederhana menjadi kata-kata yang kompleks, sehingga tulisan yang mereka buat dapat dipahami oleh pembaca.

Menurut Rosidi (2009: 2) menulis merupakan sebuah kegiatan menuangkan pikiran, gagasan, dan perasaan seseorang yang diungkapkan dalam bahasa tulis. Menulis merupakan kegiatan untuk menyatakan pikiran dan perasaan dalam bentuk tulisan yang diharapkan dapat dipahami oleh pembaca dan berfungsi sebagai alat komunikasi secara tidak langsung. Dengan demikian dapat dikatakan bahwa menulis merupakan kegiatan seseorang untuk menyampaikan kepada pembaca dalam Bahasa tulis agar bisa dipahami oleh pembaca.

Kegiatan menulis sangat penting bagi siswa karena dapat membantu mereka dalam berlatih berpikir, mengungkapkan gagasan, dan mampu memecahkan masalah. Selain itu menurut Semi (2007:14) mengatakan bahwa menulis merupakan suatu proses kreatif dalam memindahkan gagasan ke dalam lambang-lambang tulisan.

Dari kedua pernyataan di atas antara memiliki pendapat yang sama mengenai pengertian menulis. Namun sedikit berbeda yang disampaikan oleh Yunus (2015: 4) yang menyatakan bahwa menulis merupakan teks bertutur kata sesuai dengan gaya bahasa sendiri, dari yang diketahui dan dialami. Tidak ada teks yang dihasilkan tanpa kejujuran dalam diri seseorang untuk menulis. Bahan yang dituliskan pun tidak perlu jauh-jauh dari apa yang kita ketahui dan yang kita alami. Menulis menjadi alat berbagai ide dan gagasan yang subjektif dari dalam diri seseorang yang akan disampaikan kepada orang lain.

Kemudian Robert Lado dalam Resmini dan Juanda (2007:116) mengungkapkan bahwa menulis adalah menempatkan simbol-simbol grafis yang menggambarkan suatu bahasa yang dimengerti oleh seseorang. Kemudian dapat dibaca oleh orang lain yang memahami bahasa tersebut beserta simbol-simbol grafisnya. 
Pendapat para pakar di bidang menulis mengungkapkan bahwa menulis adalah melahirkan ide, pikiran, dan gagasan yang ada dalam pikiran penulis melalui tulisan yang dapat dibaca oleh para pembaca sehingga pesan yang dimaksudkan oleh penulis dapat tersampaikan dengan baik. Penulis menyimpulkan bahwa menulis merupakan kegiatan dalam menuangkan pikiran, dan gagasan kedalam bentuk tulisan dengan menggunakan gaya tulisan sendiri, baik yang diketahui mau pun yang dialami, agar pembaca mampu memahami maksud dari apa yang kita sampaikan.

\section{Pengertian Teks Biografi}

Teks biografi merupakan teks yang mengisahkan tokoh atau pelaku, peristiwa, dan masalah yang dihadapinya. Biografi merupakan riwayat hidup seseorang atau tokoh yang ditulis oleh orang lain. Teks biografi biasanya berisi tentang kehidupan seorang tokoh baik itu perjuangan maupun keberhasilan/prestasi.

Biografi berasal dari bahasa Yunani, bios yang memiliki arti hidup dan graphien yang berarti tulis. Biografi merupakan sebuah tulisan yang membahas tentang kehidupan seseorang. Secara sederhana, biografi dapat diartikan sebagai sebuah kisah riwayat hidup seseorang.

Berdasarkan Wahono, dkk menyatakan bahwa teks biografi adalah teks yang bersifat faktual yang menceritakan kehidupan tokoh berdasarkan fakta dari perjalanan hidup baik berupa penrjuangan maupun kesuksesan yang pernah diraihnya dalam kehidupan tokoh saat itu. Biasanya tokoh yang dapat dijadikan biografi adalah tokoh yang terkenal akan kesuksesan atau prestasi yang dirainya.

Pendapat Wahono, dkk diperkuat oleh pendapat dari Ima Rohima (2014: 204) teks biografi termasuk jenis teks narasi (the genre of narating) dan salah satu contoh recounted text (teks yang menceritakan sesuatu yang telah terjadi). Biografi adalah tulisan tentang riwayat hidup seseorang yang ditulis oleh orang lain.

Biografi menyajikan kisah tentang seseorang dengan menggunakan sudut orang ketiga. Biografi tentang seseorang ditulis karena keunikan dan prestasi yang dimilikinya sehingga kita dapat mengambil nilai-nilai kehidupan berdasarkan kisah yang dialami oleh tokoh dalam biografi.

Berdasarkan pendapat Ima Rohima di atas dapat disimpulan bahwa teks biografi adalah teks yang termasuk ke dalam jenis teks narasi, seperti teks yang menceritakan sesuatu yang telah terjadi sama halnya dengan teks yang ditulis sesuai dengan faktanya seperti pendapat Wahono, dkk di atas. Dalam penulisan biografi juga biasanya ditulis menggunakan sudut orang ketiga, jadi teks biografi ditulis oleh orang lain bisa juga ditulis oleh sendiri yang dimaksud dengan autobiografi

Pendapat para ahli di atas diamini oleh pendapat Nurhadi (2016:58) biografi adalah tulisan yang berisis prinsip-prinsip hidup, pandangan hidup, perjuangan, keberhasilan/prestasi, kesulitan atau masalah yang dihadapi, dan kegigihan seorang tokoh dalam menghadapi masalahmasalah itu. Berdasarkan pendapat Nurhadi (2016:58) dapat simpulkan bahwa teks biografi adalah teks yang berisi prinsipprinsip hidup, perjuangan, keberhasilan/prestasi tokoh dan masalah yang telah dihadapi seorang tokoh dalam hidupnya.

Dari pendapat para ahli di atas, dapat diketahui bahwa biografi adalah tulisan yang berisi tentang riwayat hidup seseorang yang ditulis orang lain. Riwayat hidup tersebut berupa pengalaman dalam menempuh pendidikan, pengalaman saat 
mencapai cita-cita, dan lain-lain. Bukan hanya itu saja teks biografi juga berisi prinsip-prinsip hidup, perjuangan, dan masalah-masalah yang telah dihadapi oleh tokoh. Pengalaman menarik tersebut bersifat nyata dan bukan rekaan.

\section{Metode Quantum Teaching}

Quantum Teaching adalah pendekatan proses belajar yang dapat memunculkan kemampuan dan bakat alamiah siswa dalam membangun proses pembelajaran yang efektif (Porter, 2005:3). Model pembelajaran Quantum teaching menekankan pada teknik meningkatkan kemampuan diri dan proses penyadaran akan potensi yang dimiliki.

Berdasarkan pendapat di atas dapat dikatakan bahwa metode quantum bertujuan untuk membuat pembelajaran lebih efektif pada siswa. Metode quantum memperhatikan minat dan bakat yang ada pada siswa sehingga siswa dapat mengembangkan dan meningkatkan kemampuan yang ada dalam dirinya. Dengan memperhatikan minat siswa maka siswa mampu menyadari potensi yang ada dalam dirinya. Proses pembelajaran pun akan lebih efektif dan lebih diminati siswa.

Porter (Wulandari, 2003:7) menyatakan bahwa asas utama quantum teaching adalah "Bawalah dunia mereka ke dunia kita dan antarkan dunia kita ke dunia mereka". Inilah asas utama yang merupakan dasar model quantum teaching. Hal ini dapat diartikan bahwa guru diingatkan tentang pentingnya memasuki dunia siswa dengan mengaitkan apa yang kita ajarkan dengan sebuah peristiwa, pikiran atau perasaan yang diperoleh dari kehidupan rumah, sosial atau akademis siswa. Setelah kaitan tersebut terbentuk, guru dapat membawa siswa ke dalam dunia guru dan memberikan siswa pemahaman mengenai isi dunia (De Porter, 2005:6).

Dari pendapat di atas dapat disimpulkan bahwa Metode Quantum adalah teknik pengajaran siswa yang menyangkutkan kemampuan siswa dan bakat alamiah siswa untuk meningkatkan kemampuan diri pada siswa dengan membawa dunia mereka ke dunia kita dan membawa dunia kita kepada dunia mereka. Teknik pembelajaran ini mengaitkan pula dengan sebuah peristiwa yang dialami siswa bahkan mengaitkan pikiran dan perasaan siswa. Dengan begitu siswa akan menjadi lebih tertarik dengan pembelajaran dan akan terbentuk ingatan yang kuat pada siswa mengenai apa yang dia pelajari saat belajar. Belajar memerlukan lingkungan yang menunjang, dimana anak dapat mengembangkan kemampuannya bereksplorasi dan belajar dengan efektif (Slameto, 1995:28). Hal ini perlu diperhatikan untuk membantu siswa agar responsif dan bergairah dalam proses belajar mengajar. Pengubahan lingkungan belajar yang semula membosankan menjadi lingkungan pembelajaran yang mendukung dapat membuat siswa lebih bersemangat mengikuti proses pembelajaran. Terdapat beberapa hal yang dapat dilakukan dalam menata lingkungan belajar yang mendukung proses pembelajaran, antara lain : menata lingkungan sekeliling, menggunakan alat bantu, mengatur bangku, menghadirkan tumbuhan, aroma dan hewan kesayangan, serta menghadirkan musik (Porter, 2005:63).

Dari paparan di atas dapat disimpulkan bahwa metode Quantum adalah proses pembelajaran yang menyangkut dengan minat siswa. Dengan kata lain ikut menyertakan kemampuan otak kanan pada 
siswa sehingga ingatan siswa menjadi lebih kuat dalam pembelajaran. Langkah yang digunakan adalah menggunakan prinsipprinsip TANDUR dalam metode Quantum.

\section{METODOLOGI PENELITIAN}

Penelitian ini dilaksanakan di Kelas X SMA Yayasan Purwa Bhakti Ciawi Kabupaten Bogor. Waktu penelitian dilakukan pada semester genap tanggal 11 hingga 18 Agustus 2017 selama 4 kali pertemuan.

Penelitian ini bertujuan meningkatkan keterampilan menulis teks biografi siswa pada pembelajaran Bahasa Indonesia Kelas X SMA Yayasan Purwa Bhakti Ciawi Kabupaten Bogor. Jenis penelitian ini adalah penelitian tindakan kelas. Penelitian tindakan kelas ini dilakukan secara kolaboratif dan partisipatoris. Artinya penelitian ini tidak dilakukan sendiri tetapi bekerjasama dengan guru Bahasa Indonesia kelas X SMA Yayasan Purwa Bhakti Ciawi Kabupaten Bogor.

Peneliti terlibat dengan kolaborasi bersama guru dalam perencanaan, pelaksanaan sebagai pengamat, pengamatan, dan refleksi. Peneliti sebagai pengamat jalannya pem-belajaran.

PTK, menurut Suharsimi (2006:74), terdiri atas empat kegiatan yang dilakukan dalam siklus berulang. Empat kegiatan utama setiap siklus, yaitu (a) perencanaan, (b) pelaksanaan tindakan, (c) pengamatan, dan (d) refleksi.

Penelitian menggunakan model tindakan kelas (PTK) atau Action Reseach. Model ini digunakan untuk memperbaiki dan menyempurnakan proses pembelajaran di kelas. Penelitian Tindakan Kelas (PTK) bersifat kolaboratif, oleh karena itu guru mata pelajaran Bahasa Indonesia dilibatkan untuk membantu mengobservasi dan merumuskan persoalan yang perlu diperbaiki.

Adapun langkah-langkah pelaksanaan PTK dilakukan melalui empat tahapan, yaitu (1) perencanaan tindakan (Planning), (2) pelaksanaan tindakan (action), (3) pengamatan (observing), (4) refleksi (reflecting). Hubungan keempat komponen tahapan tersebut dipandang sebagai siklus. Berikut ini alur (siklus) Penelitian Tindakan Kelas (PTK) sebagai berikut. (Arikunto, 2012:16).

Dalam model Penelitian Tindakan Kelas (PTK), langkah pertama yang harus dilakukan adalah melakukan perencanaan (planning) tindakan, misalnya membuat skenario pembelajaran atau Rencana Pelaksanaan Pembelajaran (RPP), lembar observasi, dan lain-lain. Kemudian langkah selanjutnya adalah pelaksanaan tindakan sesuai dengan Rencana Pelaksanaan Pembelajaran (RPP) yang telah dibuat sebelumnya. Pada tahap pelaksanaan tindakan, di dalamnya dilakukan pengamatan (observasi), selanjutnya melakukan analisis dan refleksi.

Jumlah siklus dalam satu penelitian akan bergantung pada kriteria keberhasilan yang telah ditentukan. Misal Jika KKM Bahasa Indonesia di kelas X sebesar 75, maka $75 \%$ dari peserta didik di kelas tersebut telah mencapai KKM penelitian di kelas tersebut dinyatakan berhasil. Tetapi jika peserta didik yang mendapatkan nilai postes kurang dari $75 \%$ maka peneliti melanjutkan penlitian disiklus berikutnya sampai kriteria keberhasilan peserta didik dalam keterampilan menulis teks negosiasi mencapai angka 76. 
Data yang dikumpulkan dalam penelitian tindakan kelas diperoleh dari peserta didik di kelas X SMA Negeri 4 Bogor, kemudian pengamatan akan dilakukan oleh dua orang guru observer yang akan berkolaborasi dengan peneliti.

\section{Cara Pengumpulan Data}

\section{Data}

Data penelitian ini berupa hasil belajar siswa tentang menulis teks biografi pada siswa kelas X SMA YAYASAN PURWA BHAKTI CIAWI yang diperoleh melalui sebagai berikut :

a. Tes

Tes yang digunakan dalam penelitian ini adalah tes tertulis. Instrument tes yang digunakan ialah soal tes. Soal yang digunakan dalam tes tertulis terbentuk esai. Bentuk tes yang diberikan adalah tes kemampuan menulis teks biografi menggunakan metode quatum (TANDUR). Tes dilakukan dalam dua tahap yaitu pada prates dan postes. Tes tersebut dilakukan untuk mengetahui peningkatan kemampuan siswa dalam menulis teks biografi menggunakan metode quantum (TANDUR)

\section{b. Observasi}

Teknik observasi yang dilakukan dalam penelitian ini yaitu teknik observasi tak bersruktur. Teknik observasi tak berstruktur dipilih karena teknik ini tidak dibatasi oleh kerangka kerja pasti dan pembatasannya hanya pada tujuan observasi ini dilakukan sehingga penliti biasa mendapatkan data yang lebih banyak untuk mendukung penelitian ini. Observasi dilakukan secara langsung oleh peneliti dengan mengamati berbagai macam tingkah laku siswa dalam proses pembelajaran. Instrument yang digunakan dalam penelitian ini yaitu pedoman observasi.

\section{Analisis Data}

a. Menentukan Nilai Tiap Siswa

$\mathrm{N}=\frac{\text { Skor }}{\text { STI }} 100$

Keterangan :

$\mathrm{N}=$ Nilai Siswa

STI = Skor Total Ideal (Arikunto,2012: 203)

b. Menentukan nilai rata-rata kelas

Rumus : $\mathrm{X}=\sum_{\mathrm{N}}^{\sum \mathrm{X}}$

Keterangan : $\mathrm{X}=$ Nilai rata-rata kelas

$$
\begin{aligned}
& \sum=\text { Jumlah Nilai } \\
& \text { N = Jumlah Siswa }
\end{aligned}
$$

(Aqib, $2010: 204$ )

b. Rumus untuk menentukan kenaikan tiap siklus adalah sebagai berikut.

$$
\begin{aligned}
& \text { Rumus } \quad: \\
& \mathrm{Pk}=\frac{(\mathrm{RS} 2-\mathrm{RS} 1)}{\mathrm{RSI}} \times 100 \%
\end{aligned}
$$

Keterangan :

$\mathrm{Pk}=$ Persentase Kenaikan

RS2 = nilai rata-rata siklus kedua

RS1 = nilai rata-rata siklus pertama

( Aqib, $2011: 53$ )

\section{HASIL PENELITIAN \\ REKAPITULASI ANALISIS DATA HASIL \\ PRATES \\ MENULIS TEKS BIOGRAFI}

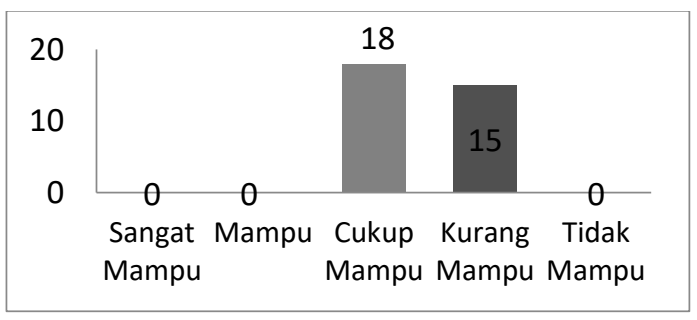


Berdasarkan rekapitulasi analisis data hasil tes menulis teks biografi pada diagram di atas, dapat diketahui bahwa peserta didik yang sangat mampu terdapat 0 peserta didik, peserta didik yang mampu terdapat 0 peserta didik, peserta didik yang cukup mampu terdapat 18 peserta didik, peserta didik yang kurang mampu terdapat 15 peserta didik, dan peserta didik yang tidak mampu tidak terlihat.

Berdasarkan data tabel di atas, kemampuan menulis teks biografi peserta didik kelas $\mathrm{X}$ A Yayasan Purwa Bhakti Ciawi Bogor belum maksimal, hal ini terbukti dari jumlah peserta didik yang cukup mampu dan kurang mampu tidak sama rata. Menurut pendapat observer hal ini terjadi karena peserta didik tidak berusaha untuk sebaik mungkin membuat teks biografi dengan baik sesuai dengan aspek menulis teks biografi walaupun tidak semua hasil teks biografi baik.

DATA HASIL POSTES KEMAMPUAN MENULIS TEKS BIOGRAFI MELALUI METODE QUANTUM (TANDUR) PADA PESERTA DIDIK KELAS X SMA YAYASAN PURWA BHAKTI CIAWI

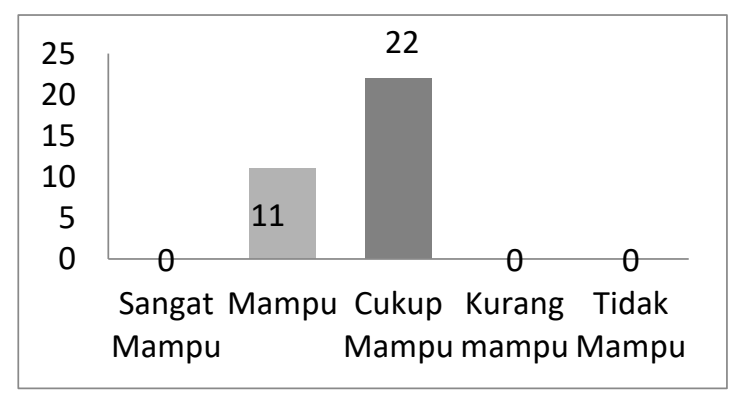

Berdasarkan tabel rekapitulasi analisis data hasil tes menulis teks biografi di atas, dapat diketahui bahwa peserta didik yang sangat mampu terdapat 0 peserta didik, peserta didik yang mampu terdapat 11 peserta didik, peserta didik yang cukup mampu terdapat 22 peserta didik, peserta didik yang kurang mampu terdapat 0 peserta didik, dan peserta didik yang tidak mampu tidak terlihat.

Berdasarkan data tabel di atas, kemampuan menulis teks biografi peserta didik kelas X A Yayasan Purwa Bhakti Ciawi Bogor tidak seimbang, hal ini terbukti dari jumlah peserta didik yang mampu dan cukup mampu tidak sama rata. Menurut pendapat observer hal ini terjadi karena peserta didik tidak berusaha untuk sebaik mungkin membuat teks biografi dengan baik sesuai dengan aspek menulis teks biografi walaupun tidak semua hasil teks biografi baik

\section{PERBANDINGAN DATA REKAPITULASI PRATES DAN POSTES SIKLUS I}

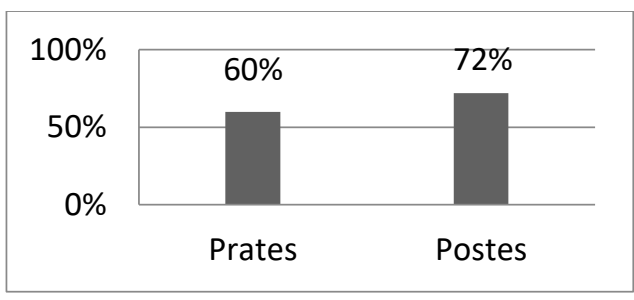

Berdasarkan data di atas, dapat terlihat bahwa penilaian rata-rata hasil prates pada siklus I sebesar 59,8. Berdasarkan kriteria keberhasilan, nilai rata-rata 59,8 termasuk kategori cukup tinggi. Nilai rata-rata postes pada siklus I sebesar 72. Berdasarkan kriteria keberhasilan, nilai rata-rata 72 termasuk kategori cukup tinggi. 
REKAPITULASI ANALISIS DATA HASIL TES MENULIS TEKS BIOGRAFI SIKLUS II

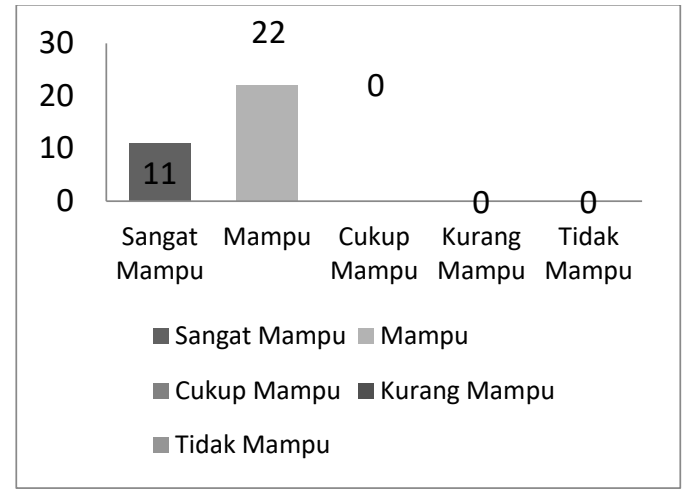

Berdasarkan tabel rekapitulasi analisis data hasil tes menulis biografi di atas, dapat diketahui bahwa peserta didik yang sangat mampu terdapat 11 peserta didik, peserta didik yang mampu terdapat 22 peserta didik, peserta didik yang cukup mampu tidak terlihat, peserta didik yang kurang mampu tidak terlihat, dan peserta didik yang tidak mampu tidak terlihat.

Berdasarkan data peserta didik, secara keseluruhan peserta didik sangat mampu menulis teks biografi dengan menggunakan metode Quantum (TANDUR).

\section{DATA REKAPITULASI POSTES SIKLUS II}

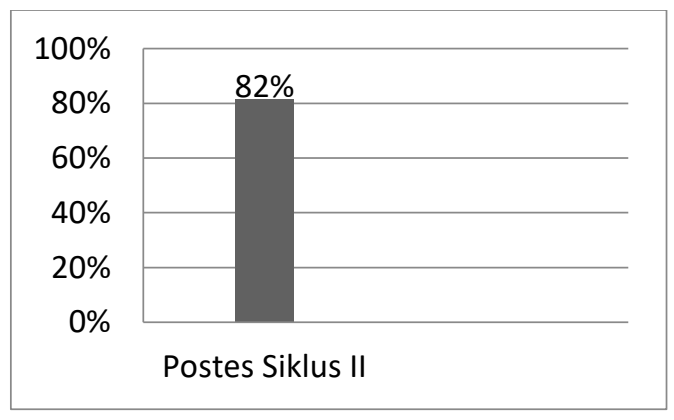

Berdasarkan data di atas, dapat terlihat bahwa pada grafik data rekapitulasi postes pada siklus II sebesar 81,6. Berdasarkan kriteria keberhasilan nilai rata-rata 81,6 termasuk kategori tinggi.

\section{PERBANDINGAN PRATES DAN POSTES SIKLUS I DAN SIKLUS II}

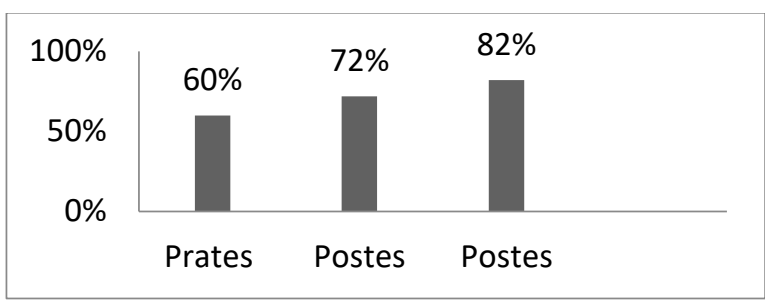

Berdasarkan grafik di atas, dapat terlihat bahwa penilaian pada siklus I rata-rata prates hasil peserta didik mencapai $60 \%$ dan postes rata-rata peserta didik mencapai $72 \%$. Sedangkan pada siklus II postes ratarata hasil peserta didik mencapai $82 \%$. Berdasarkan kriteria keberhasilan, nilai rata-rata $82 \%$ termasuk kategori tinggi. Peserta didik kelas X SMA Yayasan Purwa Bhakti Ciawi Bogor pada siklus II mendapatkan nilai di atas KKM maka penelitian dianggap sudah tuntas.

Peneliti merumuskan hipotesis sebelum melaksanakan penelitian, yaitu:

1. Terdapat peningkatan kemampuan menulis teks biografi melalui metode quantum (TANDUR) pada siswa kelas X SMA Yayasan Purwa Bhakti Ciawi Bogor.

2. Metode Quantum (TANDUR) efektif dalam peningkatan keterampilan kemampuan menulis teks biografi melalui metode quantum (TANDUR) pada siswa kelas X SMA Yayasan Purwa Bhakti Ciawi Bogor.

Berdasarkan hipotesis pada penelitian ini yaitu, terbukti hasil tes menulis teks biografi pada peserta didik kelas X SMA Yayasan Purwa Bhakti Ciawi Bogor mengalami peningkatan.

Pada awalnya peneliti melakukan prates kepada peserta didik dengan tugas membuat sebuah teks biografi dengan tema Idola. 
Dalam hal ini peneliti belum memberitahukan pengertian teks biografi, struktur teks biografi bahkan Metode quantum (TANDUR) karena peneliti tahu peserta didik pernah membuat teks biografi sebelumnya. Dalam hasil prates ini peserta didik memiliki nilai yang rata-ratanya 59,8 atau jika dipersenkan menjadi $60 \%$. Nilai ini sangat jauh dari KKM mata pelajaran bahasa Indonesia yang ada di SMA Yayasan Purwa Bhakti Ciawi Bogor yaitu 75. Hal tersebut terjadi karena siswa lupa lagi dengan menulis teks biografi dan bagaimana caranya menulis teks biografi dengan baik dan memperhatikan strukturnya.

Peningkatan tersebut dapat dibuktikan dari nilai rata-rata postes peserta didik dan persentase ketercapaiannya. Nilai rata-rata postes peserta didik pada siklus I sebesar 72 dengan persentase ketercapaian sebesar $72 \%$ dan nilai rata-rata postes pada siklus II sebesar 81,6 dengan persentase ketercapaian sebesar $82 \%$, nilai rata-rata postes awal peserta didik dalam menulis teks biografi yaitu 72 dan setelah melakukan tindakan kelas melalui metode quantum (TANDUR), nilai rata-rata postes peserta didik dalam menulis teks biografi berubah menjadi 81,6.

Selanjutnya, penggunaan metode quantum (TANDUR) efektif dalam meningkatkan kemampuan menulis teks biografi pada peserta didik kelas X SMA Yayasan Purwa Bhakti Ciawi. Hal tersebut dapat dibuktikan dengan hasil menulis teks biografi peserta didik lebih variatif, lebih hidup, lebih imajinatif karena siswa langsung membuat teks biografi serta berimajinasi dari gambar yang peserta didik lihat langsung. Selain itu menulis teks biografi melalui metode quantum
(TANDUR) ini membuat siswa tidak merasa bosan dan pembelajaran membuat teks biografi tidak terlihat monoton seperti pada umumnya.

\section{KESIMPULAN}

Berdasarkan data yang diperoleh dari hasil tes menulis teks biografi dari siklus I ke siklus II peserta didik kelas X SMA Yayasan Purwa Bhakti Ciawi Bogor melalui Metode Quantum Teaching pembelajaran mengalami peningkatan. Nilai rata-rata siklus I sebesar $72 \%$ dengan interpretasi cukup mampu, sedangkan nilai rata-rata pada siklus II mencapai $81,6 \%$ dengan interpretasi mampu. Keberhasilan metode pembelajaran Quantum Teaching terlihat pada perbedaan dari hasil siklus I dan siklus II.

\section{DAFTAR PUSTAKA}

Arikunto, Suharsimi. 2013. Prosedur Penelitian: Suatu Pendekatan Praktik. Jakarta: Rineka Cipta.

Dalman. 2012. Keterampilan Menulis. Jakarta: Raja Grafindo Persada.

Huda, M. 2013. Model-model pengajaran dan Pembelajaran. Yogyakarta: Pustaka Pelajar.

Isnatun Siti dan Umi Farida. 2013. Mahir Berbahasa Indonesia. Bogor: Yudhistira.

Mashun. 2014. Teks dalam Pembelajaran Bahasa Indonesia Kurikulum 2013. Jakarta: Raja Grafindo Persada.

Moleong, Lexy S. 2001. Metodologi Penelitian Kualitatif. Bandung:PT Remaja Rosdakarya. 
Resmini, Novi dan Dadan Juanda. 2007. Pendidikan Bahasa dan Sastra Indonesia di Kelas Tinggi. Bandung: Universitas Pendidikan Indonesia.

Semi, Antar. 2007. Dasar-dasar Keterampilan Menulis. Bandung: Penerbit Angkasa.

Sugiyono. 2015. Metode Penelitian Pendidikan. Bandung: Alfabeta.

Sugiyono. 2015. Metode Penelitian Pendidikan:Pendekatan kuantitatif, kualitatif dan $R \& D$. Bandung:Alfabeta.
Suhendra, dkk. 2012. Pedoman Penulisan Proposal dan Skripsi. Bogor: Universitas Pakuan.

Suparno dan Muhammad Yunus. 2008. Keterampilan Dasar Menulis. Jakarta: Universitas Terbuka.

Tarigan, Henry Guntur. 2008. Menulis Sebagai Suatu Keterampilan Berbahasa. Bandung: Angkasa. 
